\title{
Ownership Structure and Dividend Policy: Evidence from China
}

\author{
Yordying Thanatawee ${ }^{1}$ \\ ${ }^{1}$ Graduate School of Commerce, Burapha University, Chonburi, Thailand \\ Correspondence: Yordying Thanatawee, Graduate School of Commerce, Burapha University, Chonburi, 20131, \\ Thailand. Tel: 66-8-9795-1697. E-mail: yordying@yahoo.com
}

Received: March 17, 2014

Accepted: May 19, 2014

Online Published: July 25, 2014

doi:10.5539/ijef.v6n8p197

URL: http://dx.doi.org/10.5539/ijef.v6n8p197

\begin{abstract}
This study investigates the impact of ownership structure on dividend policies of listed companies in the Shanghai Stock Exchange over the period 2007-2011. The results show that firms with higher ownership by the largest shareholder, ownership concentration, and government ownership are more likely to pay dividends. However, the probability of paying dividends decreases when institutions hold more shares. It is also found that the magnitude of dividend payouts has a positive relationship with the ownership by the largest shareholder, ownership concentration, and government ownership but a negative relationship with the ownership by institutions and foreign investors.
\end{abstract}

Keywords: ownership structure, government ownership, institutional ownership, dividend policy, China

\section{Introduction}

In their seminal paper, Miller and Modigliani (1961) propose the dividend irrelevance hypothesis showing that, in a perfect capital market, dividend policy does not affect firm value. In practice, however, capital market is neither perfect nor complete due to various factors such as transaction costs, taxes, information asymmetries, and agency problems. These market imperfections have significant impacts on corporate dividend policies, which, in turn, significantly affect the stock price because investors are concerned about their return on investment.

Over many years since Miller and Modigliani (1961), a vast number of theoretical and empirical studies have been developed to explain why and how firms pay dividends. However, the existing literature on dividend policy is replete with the evidence from developed economies while corporate dividend policies in emerging countries can be very different from those in countries with developed capital markets. Hence, researchers have recently paid more attentions to dividend policies in emerging markets and increasingly recognized that different institutional context can affect corporate dividend policies differently (e.g., La Porta et al., 2000; Aivazian et al., 2003).

This paper examines the influence of ownership structure on dividend policy of listed firms in China, an emerging country where the structure of capital markets is strikingly different from that in the U.S. According to Wei et al. (2005), China has weak legal protection for minority shareholders and underdeveloped markets for corporate control. In addition, the ownership structure of Chinese listed firms is highly concentrated (Wang, 1999; Chen et al., 2009; Bai et al., 2013). These characteristics provide opportunities for large shareholders to expropriate minority shareholders, e.g., by not paying dividends or transferring profits to other companies under their control (Shleifer \& Vishny, 1997; Claessens et al., 2000). Therefore, dividends can help mitigate the expropriation of minority shareholders by removing free cash flows from the firms. Another distinct feature of Chinese capital market is that a number of listed companies are owned and controlled by the government. Chen et al. (2009) show that dividend payouts tend to be large when companies are controlled by the government but these dividend payments might be used for tunneling rather than for just paying out free cash flows. Likewise, Bradford et al. (2013) also find that, compared with the privately controlled firms, the state-controlled firms pay higher dividends. However, they argue that higher dividends by state-controlled firms are not driven by the tunneling motive but rather by the favorable accessibility to external capital.

The results of this paper show that ownership by the largest shareholder, ownership concentration and government ownership have positive impacts on firms' decision to pay or not to pay dividends and the magnitude of dividend payments. However, the likelihood to pay dividends and the magnitude of dividend payments decrease when institutional investors hold more shares. In addition, it is found that higher foreign 
ownership is associated with lower dividend payouts. The contributions of this paper to the existing literature are as follows. First, this paper helps shed additional light on dividend policy of listed firms in China, where the research on payout policy is still unexplored. Second, the evidence from this paper showing the positive impact of government ownership on dividend policies of Chinese firms helps corroborate the findings of prior work (i.e., Chen et al., 2009; Bradford et al., 2013). Third, this paper documents an interesting issue regarding corporate governance of Chinese listed firms, i.e., the institutional ownership has a negative impact on dividend policy of Chinese firms, suggesting that large institutional investors expropriate minority shareholders.

\section{Institutional Background and Related Literature}

\subsection{Types of Shares in Chinese Stock Exchanges}

The first stock exchange in China was opened in 1990 in Shanghai. Then, in 1991, the second stock exchange was opened in Shenzhen. The capital markets in China have experienced a dramatic growth since then. IFC (2008) reported that there were over 800 listed companies in 1998 compared to only 183 listed companies in 1993, and the total market capitalization at the end of 1997 reached US\$206 billion. Despite the large market capitalization, approximately two-thirds of the shares of most listed companies in China are still non-tradable (Wang et al., 2011).

In China, there are four classes of shares: A-shares, B-shares, H-shares, and N-shares. A-shares are mostly held and traded by individuals in the two domestic stock exchanges. B-shares are held by foreigners and some authorized domestic securities firms. B-shares are denominated in Hong Kong dollars in Shenzhen Stock Exchange and U.S. dollars in Shanghai Stock Exchange. H-shares are shares of Chinese companies listed in the Hong Kong Stock exchange and N-shares are shares of Chinese companies listed in New York Stock Exchange (Xu \& Wang, 1999; Wang et al., 2011). Therefore, A-shares are the most publicly tradable shares among domestic investors.

A-shares can be classified into four groups according to types of shareholders: the state shares, legal person shares, tradable A-shares, and employee shares. The state shares are held by the central government, local government, and state-owned enterprises. The legal person shares are owned by domestic institutions including listed companies and non-bank financial institutions such as insurance companies, securities companies, investment companies, and mutual funds. The tradable A-shares are held and traded mostly by individual investors. The employee shares are shares that offered to managers and employees of listed companies as incentive scheme (Xu \& Wang, 1999).

\subsection{Impact of Large Shareholders on Dividend Policy}

According to Xu \& Wang (1999), Wang et al. (2011), and Bai et al. (2013), the ownership structure of listed companies in China is highly concentrated in the hands of three major groups of shareholders: the state, institutions, and individuals. Xu and Wang (1999) reports that, in 1995, 58\% of outstanding shares are held by the five largest shareholders. China is also regarded as a country with weak corporate governance and poor investor protection (La Porta et al., 1999). These characteristics of Chinese capital markets tend to create the agency problem and make it likely that large shareholders expropriate minority shareholders.

Jensen (1986) suggests that dividend payments reduce corporate cash under the control of managers, thus mitigating agency cost of free cash flows. In China, however, it is difficult for shareholders, especially minority ones, to enforce managers to pay dividends to meet their demand. Indeed, it is quite clear that the shareholder who has the most influential power on corporate dividend policies in China is the government bodies, who are controlling shareholders in most listed firms in the Shanghai and Shenzhen stock exchanges (Bradford et al., 2013).

Chen et al. (2009) find that dividend payouts increase as the government owns more shares. However, they suggest that the government pays high dividends to tunnel corporate resources. Similarly, Bradford et al. (2013) find that the dividends paid by the state-controlled firms are higher than those paid by the privately-controlled firms. However, they argue that the tunneling motive is not the key factor affecting dividend policy in China. Rather, the main reason why state-controlled firms pay higher dividends is that they have more ability to raise capital than privately-controlled firms.

\section{Data and Sample}

\subsection{Data}

This study examines relationship between ownership structure and dividend policy of firms listed on the Shanghai Stock Exchange (SSE) over the period 2007-2011. The data for ownership structure is obtained from 
www.sse.com.cn, the official website of SSE. The data for dividends and firm characteristics is retrieved from www.securities.com, the database provided by the Emerging Market Information Service (EMIS). The initial sample consists of 4,045 firm-year observations. After deleting firms in banking and financial industry, outliers, and missing data, the final sample consists of 3,500 observations.

\subsection{Variables}

\subsubsection{Dividend Policy}

Following Mitton (2004) and Bradford et al. (2013), I use dividend payout ratio (DPR) as a measure for dividend policy. DPR is the cash dividend per share divided by earnings per share. PAY is a dummy variable equal to 1 if firm pays dividends but 0 otherwise.

\subsubsection{Ownership Structure Variables}

TOP1 is the percent ownership of the largest shareholder. TOP5 is the percent of shares owned by the five largest shareholders. Following Khan (2006), TOP5 is used as a proxy for ownership concentration. GOV is the percent of shares held by the government. INST is the percent of shares owned by institutional investors. INDV is the percent of shares owned by individual investors. FOREN is the percent of shares owned by foreign investors.

\subsubsection{Control Variables}

The following firm characteristics are used as control variables in regression analysis.

Return on assets (ROA) is operating income over total assets. It is used to control for profitability. The relationship between DPR and ROA is predicted to be positive since firms with higher earnings tend to pay higher dividends than firms with relatively smaller earnings.

Firm size (SIZE) is measured by the natural logarithm of total assets. Since larger firms tend to be more mature and have higher free cash flow than smaller firms, it is expected that the relationship between DPR and SIZE is positive.

Following Baba (2009), free cash flow is estimated by cash flows from operations (OCF). A positive relationship between OCF and DPR should be observed if dividends are used to mitigate agency problems, while a negative relationship between these variables suggests that managers expropriate shareholders.

According to Fama and French (2001), Market-to-book (MTB) ratio can be used as a proxy for growth opportunities. In this paper, MTB is calculated as the market value of equity over the book value of equity. It is expected that the relationship between MTB and DPR is negative because firms with higher investments are more likely to have less free cash flow and pay lower dividends.

Financial leverage (LEV) is the debt ratio calculated as total liabilities divided by total assets. Since firms with more debt should be more cash constrained and have lower ability to pay dividends, the relationship between DPR and LEV is predicted to be negative.

To control for firm's maturity, the ratio of retained earnings to total assets (RETA) is also added to the model. According to DeAngelo et al. (2006), firms with higher RETA tend to be more mature and have higher free cash flow. DeAngelo et al. (2006) and Denis and Osobov (2008) find that RETA is a positively significant factor explaining dividend payouts in many countries. Thus, a positive relationship between RETA and DPR is also expected in China.

To control for industry effects and unobservable macroeconomic effect, industry dummies and year dummies are added to the model, respectively.

\section{Empirical Results}

\subsection{Descriptive Statistics}

Table 1 reports the descriptive statistics of the sample. It shows that, on average, about $56 \%$ of the sample firms are dividend payers and the dividends paid to shareholders is only $16.81 \%$ of net income. The ownership structure of listed companies in China is highly concentrated. That is, the largest shareholder and the five largest shareholders hold $37.11 \%$ and $50.03 \%$ of total shares, respectively. These characteristics are similar to those in Thai capital market reported by Thanatawee (2013).

It is also evident that a large proportion of shares are held by government and institutional investors, with an average holding of $31.27 \%$ and $19.86 \%$, respectively, while only a small proportion of shares are held by individual and foreign investors, with an average ownership of $2.38 \%$ and $2.66 \%$, respectively. For the control variables, the average return on assets of the sample firms is $4.09 \%$; the firm size, measured by natural logarithm 
of total assets (Million RMB), is 15.14 ; the market-to-book ratio is 3.39 ; the operating cash flow is $4.84 \%$ of total assets; the debt ratio is $48.22 \%$; and the retained earnings is $7.90 \%$ of total assets.

Table 1. Descriptive statistics of variables

\begin{tabular}{ccccc}
\hline Variables & Mean & Minimum & Maximum & Std. Deviation \\
\hline DPR & 0.1681 & 0.00 & 0.99 & 0.2077 \\
PAY & 0.5556 & 0.00 & 1.00 & 0.4966 \\
TOP1 & 37.1125 & 2.20 & 85.23 & 15.6984 \\
TOP5 & 50.0293 & 3.65 & 96.00 & 15.8119 \\
GOV & 31.2717 & 0.00 & 86.15 & 23.3818 \\
INST & 19.8587 & 0.00 & 87.10 & 19.8111 \\
INDV & 2.3818 & 0.00 & 60.33 & 6.6577 \\
FOREN & 2.6616 & 0.00 & 70.57 & 8.2979 \\
ROA & 0.0409 & -0.44 & 0.50 & 0.0649 \\
SIZE & 15.1432 & 11.90 & 19.97 & 1.2349 \\
MTB & 3.3933 & 0.10 & 9.99 & 2.027 \\
LEV & 0.5178 & 0.01 & 0.94 & 0.1801 \\
OCF & 0.0484 & -0.47 & 0.55 & 0.0851 \\
RETA & 0.0790 & -0.48 & 0.58 & 0.1218 \\
\hline
\end{tabular}

\subsection{Univariate Analysis}

In this section, I examine whether Chinese firms with different ownership structure employ different dividend policies. The sample is classified into two groups (high and low) by the mean values of ownership variables. The results in Table 2 show that firms with high ownership by the largest shareholder and high ownership concentration, as indicated by TOP 1 and TOP 5 respectively, pay significantly higher dividends than firms with low ownership by the largest shareholder and low ownership concentration. Also, firms with high government ownership and foreign ownership pay higher dividends. However, firms with high institutional and individual holdings pay lower dividends than those with low institutional and individual ownership.

Table 2. Dividend payout ratio classified by ownership structure

\begin{tabular}{llll}
\hline Ownership & High & Low & Difference \\
\hline TOP1 & 0.2003 & 0.1390 & $0.0613^{* *}$ \\
& $(\mathrm{n}=1,660)$ & $(\mathrm{n}=1,840)$ & $(8.818)$ \\
TOP5 & 0.2060 & 0.1293 & $0.0766^{* *}$ \\
& $(\mathrm{n}=1,769)$ & $(\mathrm{n}=1,731)$ & $(11.102)$ \\
GOV & 0.1977 & 0.1331 & $0.0646^{* *}$ \\
& $(\mathrm{n}=1,894)$ & $(\mathrm{n}=1,606)$ & $(9.286)$ \\
INST & 0.1536 & 0.1772 & $-0.0236^{* *}$ \\
& $(\mathrm{n}=1,354)$ & $(\mathrm{n}=2,146)$ & $(-3.281)$ \\
INDV & 0.1100 & 0.1822 & $-0.0723^{* *}$ \\
& $(\mathrm{n}=685)$ & $(\mathrm{n}=2,815)$ & $(-8.242)$ \\
FOREN & 0.2010 & 0.1592 & $0.0417^{* *}$ \\
& $(\mathrm{n}=740)$ & $(\mathrm{n}=2,760)$ & $(4.869)$ \\
\hline
\end{tabular}

Note. The values reported in parentheses are t-statistics. ${ }^{* *},{ }^{*}$ denote statistically significant at the $1 \%$ and $5 \%$ levels, respectively.

\subsection{Multivariate Analysis}

The corporate dividend policy can be viewed as a two-step process: (1) to pay or not to pay and (2) how much to pay. The binary logit regression is employed in the first step to examine factors affecting firms' decisions to pay dividends. Then, the Tobit model is used to examine factors affecting the amounts of dividend payouts.

\subsubsection{Decision to Pay Dividends}

Table 3 shows the results of logit regression in which the dependent variable is a dummy variable taking value of 1 if the firm pays dividends but 0 otherwise. The results from Model 1 indicate that firms with higher ownership by the largest shareholder (TOP1) are more likely to pay dividends, a finding consistent with Truong and Heaney 
(2007) but inconsistent with Gugler and Yurtoglu (2003). Similarly, Model 2 indicates that firms with higher ownership concentration are more likely to pay dividends, a finding consistent with Thanatawee (2013). Likewise, as shown in Model 3, the probability of paying dividends increases as the government holds more shares, a finding in line with Chen et al. (2009) and Bradford et al. (2013).

Table 3. Logit analysis of firms' decisions to pay dividends

\begin{tabular}{|c|c|c|c|c|c|c|}
\hline Variable & Model 1 & Model 2 & Model 3 & Model 4 & Model 5 & Model 6 \\
\hline Intercept & $\begin{array}{l}-8.5664^{* *} \\
(-9.1565)\end{array}$ & $\begin{array}{l}-8.4914 * * \\
(-8.9804)\end{array}$ & $\begin{array}{l}-8.4955^{* *} \\
(-9.0486)\end{array}$ & $\begin{array}{l}-9.1220 * * \\
(-9.8228)\end{array}$ & $\begin{array}{l}-8.8438 * * \\
(-9.4939)\end{array}$ & $\begin{array}{l}-9.3946^{* *} \\
(-9.9454)\end{array}$ \\
\hline ROA & $\begin{array}{l}17.0629 * * \\
(10.7358)\end{array}$ & $\begin{array}{l}17.0299 * * \\
(10.7364)\end{array}$ & $\begin{array}{l}17.6422 * * \\
(10.9085)\end{array}$ & $\begin{array}{l}17.8088^{* *} \\
(10.9984)\end{array}$ & $\begin{array}{l}17.3659 * * \\
(10.9535)\end{array}$ & $\begin{array}{l}17.2365^{* *} \\
(10.9076)\end{array}$ \\
\hline OCF & $\begin{array}{l}-0.0478 \\
(-0.0798)\end{array}$ & $\begin{array}{l}-0.0477 \\
(-0.0801)\end{array}$ & $\begin{array}{l}-0.1005 \\
(-0.1692)\end{array}$ & $\begin{array}{l}-0.1197 \\
(-0.2022)\end{array}$ & $\begin{array}{l}-0.1198 \\
(-0.2019)\end{array}$ & $\begin{array}{l}-0.0729 \\
(-0.1230)\end{array}$ \\
\hline SIZE & $\begin{array}{l}0.4818^{* *} \\
(8.9502)\end{array}$ & $\begin{array}{l}0.4747 * * \\
(8.6926)\end{array}$ & $\begin{array}{l}0.4821 * * \\
(9.0113)\end{array}$ & $\begin{array}{l}0.5437 * * \\
(10.3367)\end{array}$ & $\begin{array}{l}0.5219 * * \\
(9.9177)\end{array}$ & $\begin{array}{l}0.5545^{* *} \\
(10.3979)\end{array}$ \\
\hline MTB & $\begin{array}{l}-0.1206^{* *} \\
(-4.0181)\end{array}$ & $\begin{array}{l}-0.1311 * * \\
(-4.3424)\end{array}$ & $\begin{array}{l}-0.1174 * * \\
(-3.8967)\end{array}$ & $\begin{array}{l}-0.1049 * * \\
(-3.4819)\end{array}$ & $\begin{array}{l}-0.1165^{* *} \\
(-3.9056)\end{array}$ & $\begin{array}{l}-0.1118 * * \\
(-3.7396)\end{array}$ \\
\hline LEV & $\begin{array}{l}-0.9512 * * \\
(-2.9684)\end{array}$ & $\begin{array}{l}-0.9869 * * \\
(-3.0686)\end{array}$ & $\begin{array}{l}-0.9859 * * \\
(-3.0362)\end{array}$ & $\begin{array}{l}-0.9305 * * \\
(-2.8859)\end{array}$ & $\begin{array}{l}-0.9621 * * \\
(-3.0020)\end{array}$ & $\begin{array}{l}-0.8688 * * \\
(-2.6867)\end{array}$ \\
\hline RETA & $\begin{array}{l}8.8330 * * \\
(12.2331)\end{array}$ & $\begin{array}{l}8.8535^{* *} \\
(12.2659)\end{array}$ & $\begin{array}{l}9.0467 * * \\
(12.2747)\end{array}$ & $\begin{array}{l}8.8446^{* *} \\
(12.1836)\end{array}$ & $\begin{array}{l}8.7815^{* *} \\
(12.1882)\end{array}$ & $\begin{array}{l}8.6528 * * \\
(12.1154)\end{array}$ \\
\hline TOP1 & $\begin{array}{l}0.0131 * * \\
(4.4776)\end{array}$ & & & & & \\
\hline TOP5 & & $\begin{array}{l}0.0113 * * \\
(3.7182)\end{array}$ & & & & \\
\hline GOV & & & $\begin{array}{l}0.0119 * * \\
(6.0653)\end{array}$ & & & \\
\hline INST & & & & $\begin{array}{l}-0.0075 * * \\
(-3.3575)\end{array}$ & & \\
\hline INDV & & & & & $\begin{array}{l}-0.0069 \\
(-1.0346)\end{array}$ & \\
\hline FOREN & & & & & & $\begin{array}{l}-0.0104 \\
(-1.8762)\end{array}$ \\
\hline Year dummies & yes & yes & yes & yes & yes & yes \\
\hline Industry dummies & yes & yes & yes & yes & yes & yes \\
\hline Total obs. & 3,500 & 3,500 & 3,500 & 3,500 & 3,500 & 3,500 \\
\hline Pseudo $\mathrm{R}^{2}$ & $30.74 \%$ & $30.61 \%$ & $31.09 \%$ & $30.58 \%$ & $30.36 \%$ & $30.40 \%$ \\
\hline
\end{tabular}

Note. Dependent variable is a dummy variable equal to 1 for dividend-paying firms $(\mathrm{n}=1,955)$ and 0 for no-paying firms $(\mathrm{n}=1,545)$. The values reported in parentheses are Huber/White standard errors $z$-statistics. **, * denote statistically significant at the $1 \%$ and $5 \%$ levels, respectively.

In contrast, Model 4 indicates that higher institutional ownership is associated with lower probability to pay dividends. This finding is consistent with Renneboog and Trojanowski (2007) but in contrast with Khan (2006) and Thanatawee (2013), and Fairchild et al. (2014). The results in Model 5 and 6, however, do not show any significant impact of individual and foreign ownership on firms' decisions to pay dividends. Consistent with DeAngelo et al. (2006), Dennis and Osobov (2008) and Thanatawee (2013), it is found that the likelihood to pay dividends has positive relationship with profitability (ROA), firm size (SIZE), and retained earnings (RETA) but negative relationship with growth opportunities (MTB) and financial leverage (LEV). However, the operating cash flow does not have significant impact on the likelihood to pay dividends.

\subsubsection{Magnitude of Dividend Payouts}

I proceed to analyze factors affecting the dividend payouts of Chinese firms. Tobit analysis is used instead of OLS because many firms choose not to pay dividends. This gives rise to a special feature of the dependent variable which is either zero or positive number. Exclusion of non-dividend-paying firms and perform OLS will result in selection bias (Kim \& Maddala, 1992). 
Table 4. Tobit analysis of dividend payouts

\begin{tabular}{|c|c|c|c|c|c|c|}
\hline Variable & Model 1 & Model 2 & Model 3 & Model 4 & Model 5 & Model 6 \\
\hline Intercept & $\begin{array}{l}-0.7899 * * \\
(-7.6437)\end{array}$ & $\begin{array}{l}-0.7459^{* *} \\
(-7.0676)\end{array}$ & $\begin{array}{l}-0.7903 * * \\
(-7.6603)\end{array}$ & $\begin{array}{l}-0.9036^{* *} \\
(-8.7617)\end{array}$ & $\begin{array}{l}-0.8941 * * \\
(-8.6009)\end{array}$ & $\begin{array}{l}-0.9648 * * \\
(-8.7792)\end{array}$ \\
\hline ROA & $\begin{array}{l}0.9256^{* *} \\
(6.2426)\end{array}$ & $\begin{array}{l}0.9261 * * \\
(6.2643)\end{array}$ & $\begin{array}{l}0.9819^{* *} \\
(6.4424)\end{array}$ & $\begin{array}{l}0.9953^{* *} \\
(6.4938)\end{array}$ & $\begin{array}{l}0.9733^{* *} \\
(6.4267)\end{array}$ & $\begin{array}{l}0.9547^{* *} \\
(6.3029)\end{array}$ \\
\hline $\mathrm{OCF}$ & $\begin{array}{l}0.0263 \\
(0.3493)\end{array}$ & $\begin{array}{l}0.0268 \\
(0.3541)\end{array}$ & $\begin{array}{l}0.0197 \\
(0.2612)\end{array}$ & $\begin{array}{l}0.0252 \\
(0.0333)\end{array}$ & $\begin{array}{l}0.0241 \\
(0.3178)\end{array}$ & $\begin{array}{l}0.0306 \\
(0.4041)\end{array}$ \\
\hline SIZE & $\begin{array}{l}0.0415^{* *} \\
(7.2253)\end{array}$ & $\begin{array}{l}0.0371 * * \\
(6.1871)\end{array}$ & $\begin{array}{l}0.0433^{* *} \\
(7.6463)\end{array}$ & $\begin{array}{l}0.0533^{* *} \\
(9.5211)\end{array}$ & $\begin{array}{l}0.0522 * * \\
(9.2758)\end{array}$ & $\begin{array}{l}0.0565^{* *} \\
(9.4033)\end{array}$ \\
\hline MTB & $\begin{array}{l}-0.01595^{* *} \\
(-4.2286)\end{array}$ & $\begin{array}{l}-0.0186^{* *} \\
(-4.3424)\end{array}$ & $\begin{array}{l}-0.0157 * * \\
(-4.2032)\end{array}$ & $\begin{array}{l}-0.0145^{* *} \\
(-3.8167)\end{array}$ & $\begin{array}{l}-0.0154 * * \\
(-4.0793)\end{array}$ & $\begin{array}{l}-0.0147 * * \\
(-3.8668)\end{array}$ \\
\hline LEV & $\begin{array}{l}-0.0562 \\
(-1.2953)\end{array}$ & $\begin{array}{l}-0.0667 \\
(-1.5336)\end{array}$ & $\begin{array}{l}-0.0585 \\
(-1.3405)\end{array}$ & $\begin{array}{l}-0.0478 \\
(-1.0866)\end{array}$ & $\begin{array}{l}-0.0497 \\
(-1.1332)\end{array}$ & $\begin{array}{l}-0.0383 \\
(-0.8626)\end{array}$ \\
\hline RETA & $\begin{array}{l}0.9838^{* *} \\
(12.9412)\end{array}$ & $\begin{array}{l}0.9901 * * \\
(13.0966)\end{array}$ & $\begin{array}{l}0.9943 * * \\
(12.8882)\end{array}$ & $\begin{array}{l}0.9791 * * \\
(12.6864)\end{array}$ & $\begin{array}{l}0.9759^{* *} \\
(12.7158)\end{array}$ & $\begin{array}{l}0.9672 * * \\
(12.6188)\end{array}$ \\
\hline TOP1 & $\begin{array}{l}0.0025 * * \\
(6.4185)\end{array}$ & & & & & \\
\hline TOP5 & & $\begin{array}{l}0.0027 * * \\
(6.8015)\end{array}$ & & & & \\
\hline GOV & & & $\begin{array}{l}0.0017 * * \\
(6.5411)\end{array}$ & & & \\
\hline INST & & & & $\begin{array}{l}-0.0007^{*} \\
(-2.2144)\end{array}$ & & \\
\hline INDV & & & & & $\begin{array}{l}-0.0002 \\
(-0.2603)\end{array}$ & \\
\hline FOREN & & & & & & $\begin{array}{l}-0.0015^{*} \\
(-2.2833)\end{array}$ \\
\hline Year dummies & yes & yes & yes & yes & yes & yes \\
\hline Industry dummies & yes & yes & yes & yes & yes & yes \\
\hline Total obs. & 3,500 & 3,500 & 3,500 & 3,500 & 3,500 & 3,500 \\
\hline Log likelihood & $-1,312.49$ & $-1,311.77$ & $-1,311.05$ & $-1,329.89$ & $-1,332.64$ & $-1,330.40$ \\
\hline
\end{tabular}

Note. The values reported in parentheses are Huber/White standard errors z-statistics. ${ }^{* *}, *$ denote statistically significant at the $1 \%$ and $5 \%$ levels, respectively.

Table 4 shows the results of Tobit estimation in which the dependent variable is the dividend payout ratio and the independent variables are ownership structure and firm characteristics. Consistent with Truong and Heaney (2007), Model 1 shows that there is a positive relationship between the ownership of the largest shareholder and the magnitude of dividend payouts. Model 2 also shows a positive coefficient of ownership concentration (TOP5) on dividend payout ratio, a finding consistent with Thanatawee (2013) but in contrast with Khan (2006) and Harada and Nguyen (2011). Likewise, Model 3 indicates that the ownership of the government has a positive relationship with dividend payout ratio, a finding in line with those of Chen et al. (2009) and Bradford et al. (2013). On the contrary, Model 4 show that the magnitude of dividend payouts is lower when institutions hold more shares, a finding consistent with Renneboog and Trojanowski (2007) but in contrast with Khan (2006) and Thanatawee (2013), and Fairchild et al. (2014). It is found, in Model 6, that the ownership by foreign investors has a negative impact on dividend payouts, a finding in contrast with Baba (2009) and Jeon et al. (2011).

For the controlling variables, the results show that the coefficients on ROA, SIZE, and RETA are significantly positive while the coefficient on MTB is significantly negative. These results indicate that larger firms with higher profitability and more retained earnings pay higher dividends and firms with higher growth opportunities pay lower dividends. These findings are consistent with those of prior literature such as DeAngelo et al. (2006), Dennis and Osobov (2008), and Thanatawee (2011), and Thanatawee (2013).

\section{Conclusion}

This paper examines the effects of ownership structure on dividend policy of listed companies in the Shanghai Stock Exchange over the period 2007-2011. The evidence reveals that the ownership structure in China is highly concentrated and the government holds the largest percentage of shares in most companies. The ownership concentration and government ownership, nevertheless, appear to be beneficial to minority shareholders in terms 
of dividend payments as the results indicate the positive impacts of ownership concentration and government ownership on both the likelihood that firms pay dividends and the magnitude of dividend payouts. On the other hand, the shareholdings by large institutional and foreign investors could be detrimental to shareholders' wealth since the results indicate that the likelihood to pay dividends and magnitude of dividend payouts decrease when institutions hold more shares. Similarly, it is found that firms pay lower dividends when foreign investors hold more shares. Hence, the evidence suggests that large institutional and foreign investors expropriate minority shareholders.

\section{Acknowledgements}

I would like thank Gou Jieping for his assistance in the data collection process.

\section{References}

Aivazian, V., Booth, L., \& Cleary, S. (2003). Dividend policy and the organization of capital markets. Journal of Multinational Financial Management, 13, 101-121. http://dx.doi.org/10.1016/S1042-444X(02)00038-5

Baba, N. (2009). Increased presence of foreign investors and dividend policy of Japanese firms. Pacific-Basin Finance Journal, 17, 163-174. http://dx.doi.org/10.1016/j.pacfin.2008.04.001

Bai, Y., Lin, B. X, Wang, Y., \& Wu, L. (2013). Corporate ownership, debt, and expropriation: Evidence from China. China Journal of Accounting Studies, 1, 13-31. http://dx.doi.org/10.1080/21697221.2013.781771

Bradford, W., Chen, C., \& Zhu, S. (2013). Cash dividend policy, corporate pyramids, and ownership structure: Evidence from China. International Review of Economics and Finance, 27, 445-464. http://dx.doi.org/10.1016/j.iref.2013.01.003

Chen, D., Jian, M., \& Xu, M. (2009). Dividends for tunneling in a regulated economy: The case of China. Pacific Basin Finance Journal, 17, 209-223. http://dx.doi.org/10.1016/j.pacfin.2008.05.002

Claessens, S., Djankov, S., \& Lang, L. H. P. (2000). The separation of ownership and control in East Asian $\begin{array}{lllll}\text { corporations. Journal of } & \text { Financial }\end{array}$ http://dx.doi.org/10.1016/S0304-405X(00)00067-2

DeAngelo, H., DeAngelo, L., \& Stulz, R. M. (2006). Dividend policy and the earned/contributed capital mix: A test of the life-cycle theory. Journal of Financial Economics, 81, 227-254. http://dx.doi.org/10.1016/j.jfineco.2005.07.005

Denis, D. J., \& Osobov, I. (2008). Why do firms pay dividends? International evidence on the determinants of $\begin{array}{lllll}\text { dividend policy. Journal of Financial Economics, } & 89,\end{array}$ http://dx.doi.org/10.1016/j.jfineco.2007.06.006

Fairchild, R., Guney, Y., \& Thanatawee, Y. (2014). Corporate dividend policy in Thailand: Theory and evidence. International Review of Financial Analysis, 31, 129-151. http://dx.doi.org/10.1016/j.irfa.2013.10.006

Fama, F. E., \& French, K. R. (2001). Disappearing dividends: Changing firm characteristics or lower propensity to pay? Journal of Financial Economics, 60, 3-43. http://dx.doi.org/10.1016/S0304-405X(01)00038-1

Gugler, K., \& Yurtoglu, B. (2003). Corporate governance and dividend payout in Germany. European Economic Review, 47, 731-758. http://dx.doi.org/10.1016/S0014-2921(02)00291-X

Harada, K., \& Nguyen, P. (2011). Ownership concentration and dividend policy in Japan. Managerial Finance, 37, 362-379. http://dx.doi.org/10.1108/03074351111115313

Jensen, M. (1986). Agency costs of free cash flow, corporate finance and takeovers. American Economic Review, 76, 323-329. http://dx.doi.org/10.2139/ssrn.99580

Jeon, J. Q., Lee, C., \& Moffett, C. M. (2011). Effects of foreign ownership on payout policy: Evidence from the Korean market. Journal of Financial Markets, 14, 344-375. http://dx.doi.org/10.1016/j.finmar.2010.08.001

Khan, T. (2006). Company dividends and ownership structure: Evidence from UK panel data. The Economic Journal, 116, 172-189. http://dx.doi.org/10.1111/j.1468-0297.2006.01082.x

Kim, B. S., \& Maddala, G. S. (1992). Estimation and specification analysis models of dividends behavior based on censored panel data. Empirical Economics, 17, 111-124. http://dx.doi.org/10.1007/BF01192478

LaPorta, R., Lopez-de-Silanes, F., Shleifer, A., \& Vishny, R. W. (2000). Agency problems and dividend policies around the world. Journal of Finance, 55, 1-33. http://dx.doi.org/10.1111/0022-1082.00199

Miller, M., \& Modigliani, F. (1961). Dividend policy, growth, and the valuation of shares. Journal of Business, 
34, 411-433. http://dx.doi.org/10.1086/294442

Renneboog, L., \& Trojanowski, G. (2007). Control structures and payout policy. Managerial Finance, 33, 4364. http://dx.doi.org/10.1108/03074350710715809

Shleifer, A., \& Vishny, R. (1986). Large shareholders and corporate control. Journal of Political Economy, 95, 461-488. http://dx.doi.org/10.1086/261385

Thanatawee, Y. (2011). Life-cycle theory and free cash flow hypothesis: Evidence from dividend policy in Thailand. International Journal of Financial Research, 2, 52-60. http://dx.doi.org/10.5430/ijfr.v2n2p52

Thanatawee, Y. (2013). Ownership structure and dividend policy: Evidence from Thailand. International Journal of Economics \& Finance, 5, 121-132. http://dx.doi.org/10.5539/ijef.v5n1p121

Truong, T., \& Heaney, R. (2007). Largest shareholder and dividend policy around the world. The Quarterly Review of Economics and Finance, 47, 667-687. http://dx.doi.org/10.1016/j.qref.2007.09.002

Wang, X., Manry, D., \& Wandler, S. (2011). The impact of government ownership on dividend policy in China. Advances in Accounting, 27, 366-372. http://dx.doi.org/10.1016/j.adiac.2011.08.003

Wei, Z., Xie, F., \& Zhang, S. (2005). Ownership structure and firm value in China's privatized firms: 19912001. Journal of Financial and Quantitative Analysis, 40, 87-107. http://dx.doi.org/10.1017/S0022109000001757

Xu, X., \& Wang, Y. (1999). Ownership structure and corporate governance in Chinese stock companies. China Economic Review, 10, 75-98. http://dx.doi.org/10.1016/S1043-951X(99)00006-1

\section{Copyrights}

Copyright for this article is retained by the author(s), with first publication rights granted to the journal.

This is an open-access article distributed under the terms and conditions of the Creative Commons Attribution license (http://creativecommons.org/licenses/by/3.0/). 